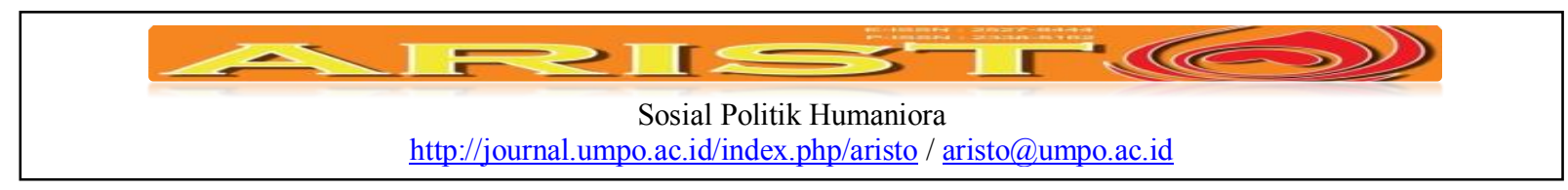

\title{
Brexit : Eurosceptic Victory In British Referendum In Term Of Britain Membership Of European Union
}

\author{
Khairul Munzilin, Ali Muhammad \\ Program Studi Ilmu Hubungan Internasional, FISIP, \\ Universitas Muhammadiyah Yogyakarta \\ kmunzilin@gmail.com, alimuhammad@umy.ac.id
}

\begin{abstract}
On June 23, 2016, eurosceptic group won a British referendum on Britain's motion of leaving the European Union. This paper will explore the factors related to the victory of eurosceptic group in the historic referendum. This paper uses theory of voting behaviour and strategy of campaign to answer the research of this paper. Eurosceptic group victory in this referendum couldn't be separated from eurosceptic's success in influencing the mindset of Britishsociety as the voter in this referendum. By using the concept of the campaign strategy, the writer will examine various forms of brexit campaign strategy that used to influence voters behaviour.
\end{abstract}

Keyword : Brexit, Eurosceptic, United Kingdom, European Union, Referendum

\begin{abstract}
Abstrak
Pada tanggal 23 Juni 2016, kelompok eurosceptic memenangkan referendum Inggris terkait mosi Inggris untuk keluar dari Uni Eropa. Tulisan ini akan membahas terkait faktor-faktor kemenangan kelompok eurosceptic dalam sejarah referendum Inggris. Dalam menjawab permasalahan dalam tulisan ini penulis menggunakan teori voting behaviour dan konsep strategi kampanye. Kemenangan kelompok eurosceptic tidak dapat dipisahkan dari kemampuan kelompok ini dalam mempengaruhi pola pikir dari masyarakat dan para pemilih referendum Inggris. Dengan menggunakan konsep strategi kampanye penulis akan mengkaji berbagai strategi kelompok eurosceptic dalam referendum Inggris.
\end{abstract}

Keyword : Brexit, Eurosceptic, United Kingdom, European Union, Referendum

\begin{tabular}{|ll}
\hline Submite & $:$ 14 Nov 2016 \\
Review & $:$ 25 Nov 2016 \\
Accepted & $:$ 01 Jan 2017 \\
Surel Corespondensi & $:$ darwisnasution@gmail.com \\
\hline
\end{tabular}

\section{Pendahuluan}

Kemenangan kelompok euroskeptis di Inggris dalam referendum tentang status keanggotaan Inggris di Uni Eropa tahun 2016 merupakan peristiwa penting bagi Inggris. Referendum itu diawali dengan janji Perdana Menteri David Cameron bulan Februari 2016 bahwa Inggris akan mengadakan referendum terkait "apakah Inggris akan menetap sebagai anggota dari Uni Eropa," atau“ apakah Inggris akan melepaskan diri dari keanggotaannya di Uni 


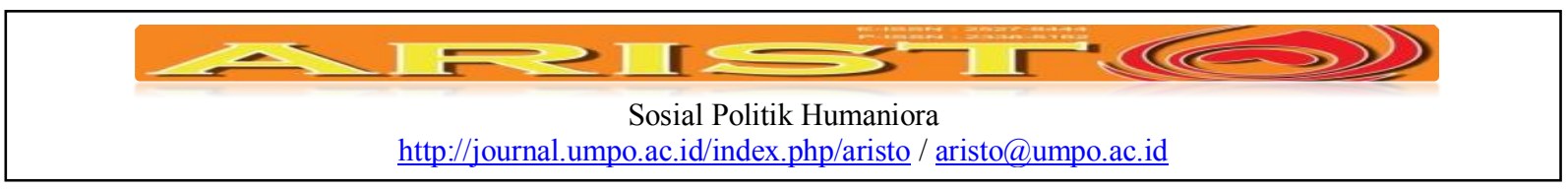

Eropa" Referendum yang awalnya ditargetkan pada 2017 menjadi lebih awal dan akan dilaksanakan pada tanggal 23 juni 2016, pemutusan pertanggalan ini lahir setelah diadakannya renegosiasi terhadap hubungan Inggris dengan Uni Eropa di Brusel pada bulanapril 2015. Sedangkan keputusan referendum ini muncul dari pemungutan suara parlemen Inggris setelah perdebatan yang lama terkait RUU referendum ini, dalam pemungutan suara ini anggota parlement yang mendukung pembuatan RUU ini berjumlah 544 orang sedangkan yang menolak berjumlah 53 orang (BBC, 2015). Referendum ini tonggak penting bagi masa depan Inggris. Keputusan apakah Inggris akan keluar atau tetap menjadi anggota Uni Eropa tidak bergantung pada keputusan para birokrat yang duduk di kursi pemerintahan. Namun masyarakat Inggris secara keseluruhan yang akan menjadi penentu terhadap keputusan yang akan diambil. Hal ini menjelaskan bahwa Referendum mendapat tempat penting bagi keputusan Inggris terkait keanggotaan Inggris di Uni Eropa. Pada bulan Februari 2016, setelah pertemuan KTT Uni Eropa di Brussels telah usai, Perdana Menteri Inggris, David Cameron mengumumkan bahwa para pemimpin negara Uni Eropa telah mencapai kesepakatan untuk memberikan berbagai "status spesial" sebagai pertimbangan agar Inggris tidak keluar dari blok itu. Meski demikian, keanggotaan Inggris di Uni Eropa akan ditentukan rakyat Inggris sendiri melalui referendum. Usai diskusi selama dua hari yang berlangsung di Brussels, para pemimpin Uni Eropa sepakat dengan suara bulat untuk menerapkan sejumlah langkah yang bertujuan membuat Inggris tetap berada di Uni Eropa (Sari, 2016).

Dari berbagai survey polling yang dilaksanakan secara independen sebelum referendum, ComRes menempatkan kubu Bremain lebih unggul 12 poin dibandingkan kubu brexit, dengan 51\% dari pemilih menginginkan Inggris untuk menetap di Uni Eropa dan 39\% memutuskan untuk meninggalkan Uni Eropa. Sebuah survei online dari You Gov menyatakan bahwa 42\% memutuskan untuk meninggalkan Uni Eropa, sementara 38\% imemutuskan untuk menetap di Uni Eropa. Hasil ini konsisten dengan tren selama beberapa bulan terakhir sebelum referendum dimulai, yang menunjukkan bremain memimpin dalam jajak pendapat telepon dan kompetisi yang ketat antara brexit dan bremain dalam sampel online (Fishwick, 2016).

Demikian pula, dalam report yang dikeluarkan oleh guardian.com pada 23 februari 2016 terkait pilihan anggota parlemen terhadap setengah lebih dari MPs Inggris, menunjukan hasil bahwa pilihan Bremain menjadi pilihan terbanyak dibandingkan pilihan untuk brexit dan abstain. Guardian telah mendata sebanyak 638 orang dari 650 orang anggota parlemen Inggris raya, 


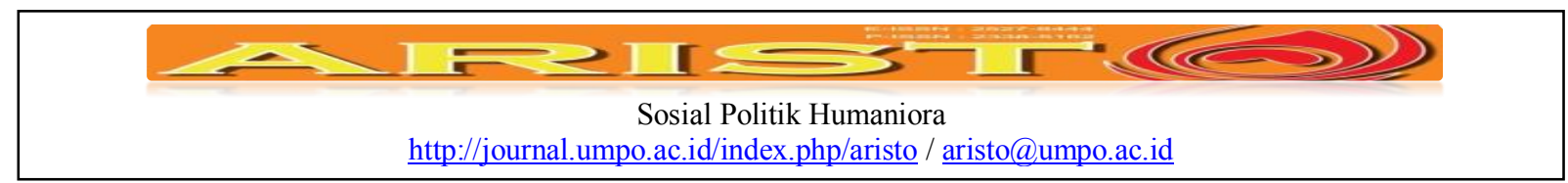

dalam surveynya gurdian membagi tiga klasifikasi pilihan dengan pertama pilihan untuk Inggris meninggalkan Uni Eropa, kedua pilihan untuk Inggris tetap menjadi bagian dari Uni Eropa, dan terakhir pilihan untuk mereka yang belum menentukan pilihan mereka antara kedua pilihan yang ada. Dari 638 orang yang mengikuti survey ini menunjukan bahwa mereka yang memilih brexit berjumlah 138 orang, yang memilih bremain berjumlah 417 orang, dan mereka yang belum menentukan pilihannya berjumlah 83 orang (Mason, 2016). Secara keseluruhan hasil survey diatas menunjukkn hasil yang variatif namun tetap merefleksikan bahwa mayoritas masyarakat Inggris kelihatannya menginginkan Inggris untuk tetap menjadi bagian dari Uni Eropa. Berdasarkan hasil polling sebelum referendum dan hasil penghitungan suara pada referendum, fenomena ini merefleksikan suatu kejadian yang kontradiktif. Ketiga poling diatas menunjukan "Bremain" lebih unggul dibandingkan dengan "brexit". Namun hasil referendum menunjukkan bahwa "brexit menjadi pemenang dalam referendum tersebut. Mengapakelompok Brexit menangdalam referendum.

\section{Metode}

\section{Teori Voting Behaviour}

Dalam menjawab permasalahan diatas penulis akan menggunakan teori voting behaviour. Teori Voting Behaviour terdiri dari dua kata yaitu Voting dan Behaviour, voting dalam bahasa indonesia berarti pemberian suara yang menurut marriam-webster ditafsirkan sebagai pilihan resmi yang dibuat dalam pemilihan, rapat, dan lainnya, dengan menggunakan surat suara, mengangkat tangan, berbicara degan nada keras, dan sebagainya (merriam-webster, 2016). Sedangkan dalam kamus Oxford, voting ialah sebuah indikasi formal pilihan antara dua atau lebih calon atau program aksi, yang biasanya dinyatakan melalui pemungutan suara atau mengacungkan tangan (oxforddictionaries.com, 2016).

Behaviour dalam bahasa indonesia berarti Perilaku, dalam sebuah jurnal yang diterbitkan oleh UNESCO, behaviour didefinisikan sebagai cara dimana seorang individu berperilaku atau bertindak. Ini adalah cara seorang individu mengendalikan dirinya. Perilaku harus dilihat dalam referensi untuk sebuah fenomena, suatu benda atau orang. Hal ini dapat dilihat dalam referensi untuk norma-norma masyarakat, atau cara di mana seseorang memperlakukan orang lain atau menangani benda. Oleh karena itu, perilaku adalah cara individu bertindak terhadap orang, masyarakat atau benda. Hal ini dapat baik atau buruk, bisa normal atau abnormal sesuai dengan 


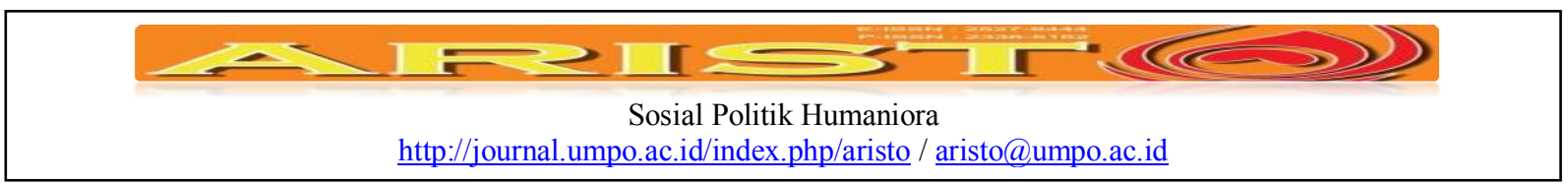

norma-norma masyarakat (Unesco, 2000). Kemenangan sebuah kelompok dalam suatu pemilu ataupun referendum dalam kasus ini, erat kaitannya dengan kemampuan kelompok tersebut dalam menguasai ataupun mempengaruhi perilaku pemilih dalam pemilu atau referendum tersebut. Antara awal 1940-an dan 1960-an, empat model dasar "perilaku pemilih" telah dikemukakan di hampir semua studi terkait perilaku pemilu. Model ini menjelaskan bagaimana manusia bereaksi terhadap faktor-faktor lingkungan dan memilih antara berbagai tindakan yang berbeda (Arzheimer, 2008). Pada dasarnya ada beberapa faktor penting yang mempengaruhi perilaku pemilih dalam sebuah pemilu, Heywood (2013) mengemukakan bahwa setidaknya terdapat empat faktor yang mempengaruhi 'perilaku pemilih'; pertama, model identifikasi partai; kedua, model sosiologi; ketiga, model pilihan rasional; keempat, model idiologi dominan. Model identifikasi partai merupakan model yang didasarkan pada rasa keterikatan atau keberpihakan psychologycal seorang terhadap suatu partai tertentu. Pemilih dilihat sebagai orang yang mengidentifikasi pilihannya dalam suatu pemilihan berdasarkan partai yang mereka anggap baik menurut kepercayaan mereka. Keikutsertaan dalam pemilihan merupakan manifestasi dari keberpihakan, bukan produk dari perhitungan yang dipengaruhi oleh faktor-faktor seperti kebijakan, kepribadian, kampanye dan liputan media (Heywood, 2013).

Model sosiologis merupakan model yang menghubungkan perilaku pemilih dengan keanggotaan kelompok tertentu, model ini menunjukkan bahwa pemilih cenderung mengadopsi pola voting yang mencerminkan posisi ekonomi dan sosial dari kelompok dimana mereka berasal. Apabila dalam model psikologis pemilih dipengaruhi dengan ikatan dengan partai atas dasar kekeluargaan, maka model sosiologis melihat bahwa pentingnya keselarasan sosial yang dicerminkan dengan berbagai divisi dan berbagai kecenderungan dalam masyarakat. Beberapa hal yang paling signifikan dari divisi-divisi ini yaitu kelas sosial, gender, budaya, agama dan daerah (Heywood, 2013).

Model pilihan rasional mengalami pergeseran perhatian pada individu, dan jauh dari sosialisasi dan perilaku kelompok sosial. Dalam pandangan model ini, voting dipandang sebagai tindakan yang rasional, dalam arti bahwa pemilih individu diyakini memutuskan preferensi partai mereka atas dasar kepentingan pribadi. Alih-alih menjadi kebiasaan, manifestasi dari lampiran yang lebih luas dan kesetiaan, voting dipandang sebagai dasarnya berperan, yaitu sebagai alat untuk mencapai tujuan. model pilihan rasional berbeda dalam beberapa hal, sebagai contoh, beberapa melihat pemilihan sebagai komentar retrospeksi pada partai yang berkuasa dan 


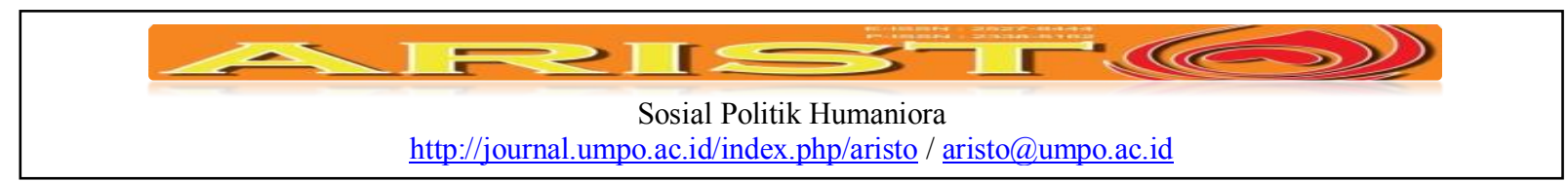

bagaimana kinerjanya memiliki pengaruh bagi warga negara. Lainnya, mereka berperilaku seperti konsumen mengekspresikan pilihan antara pilihan kebijakan yang tersedia (Heywood, 2013).

Model ideologi dominan cenderung melihat sejauh mana pilihan individu dibentuk oleh proses manipulasi dan kontrol oleh ideologi. Dalam beberapa hal teori tersebut menyerupai model sosiologis, dalam voting terlihat untuk mencerminkan posisi seseorang dalam hirarki sosial. Namun, walaubagaimanapun teori ini tetaplah berbeda dari model sosiologis, model ini lebih menekankan bagaimana kelompok dan individu menginterpretasikan posisi mereka sebagaimana telah disajikan kepada mereka melalui pendidikan, pemerintah dan maupun oleh media massa. Berbeda dengan pandangan sebelumnya yang bahwa media hanya memperkuat preferensi yang sudah ada, model ini menunjukkan bahwa media dapat mendistorsi aliran komunikasi politik, baik dengan menetapkan agenda untuk diperdebatkan dan dengan penataan preferensi dan simpati (Heywood, 2013).

\section{Konsep Strategi Kampanye}

Dalam penelitian ini, selain menggunakan teori Voting Behaviour, penulis juga akan menggunakan konsep strategi kampenye sebagai alat pembantu dalam menemukan jawaban dari penelitian ini. Segala bentuk pertandingan, peperangan bahkan kompetisi sering kali dimenangkan oleh tim ataupun kelompok yang memiliki strategi yang paling baik. Tidak terkecuali dalam pemilihan, baik pemilu maupun referendum, partai ataupun kelompok yang menang seringkali kelompok yang memiliki strategi yang paling baik. Strategi merupakan sebuah kompas bagi sebuah kampanye, Tanpa perencanaan strategi, kampanye akan berubah menjadi serangkaian kegiatan yang tidak terkonsep dan tanpa arah. Strategi berfungsi untuk mendefinisikan tujuan dan menunjukkan bagaimana mereka dapat dicapai. Perencanaan kampanye layaknya seperti membangun rumah. Hal pertama yang perlu dilakukan ialah menentukan apa yang akan dibangun dan dimana akan dibangun; maka Anda meletakkan dasar, di mana Anda membuat struktur terlihat dan bekerja pada rincian. Fondasi dari kampanye kampanye ialah target yang jelas sedangkan blue printnya ialah perencanaan kampanye(Eckert, 2014) 


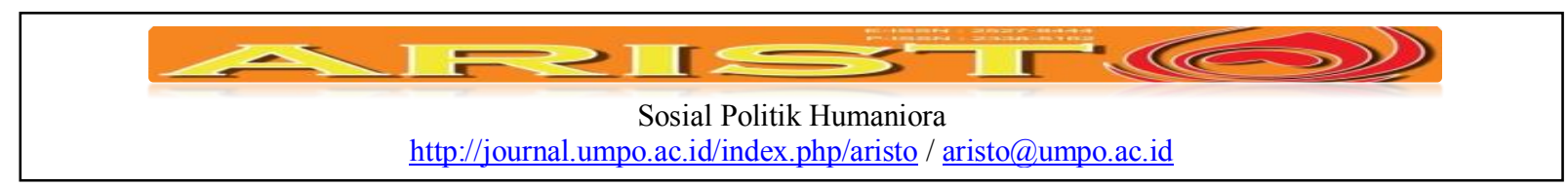

\section{Hasil dan Pembahasan}

\section{Teori Voting Behaviour}

Berlandaskan teori Heywood tersebut, keberhasilan suatu kubu dalam mempengaruhi perilaku pemilih dalam sebuah pemilihan (pemilihan umum maupun referendum) berbanding lurus pada kemenangan dalam pemilihan terkait. Dalam pembahasan ini penulis tidak akan membahas terkait model pilihan rasional. Hal ini dikarenakan penulis melihat bahwa model ini tidak memiliki pengaruh yang signifikan dalam penelitian ini. Maka, penulis menggunakan hanya tiga model dari teori Voting Behaviour, yaitu model sosiologi, model dominasi ideologi, dan model identifikasi partai, penulis akan mencoba menyelami terkait dominasi sikap pemilih yang terdapat dalam referendum Inggris 2016.

\section{Model Sosiologi: Pekerja Buruh, Purnakaryawan, dan Demografi Masyarakat Inggris}

Hasil referendum Inggris 2016 merefleksikan keberhasilan kelompok eurosceptic dalam mempengaruhi masyarakat melalui latar belakang yang mereka miliki. Berdasarkan model sosiologi, dalam referendum ini kelompok eurosceptic memfokuskan sasaran pada beberapa kelas tertentu, fokus utama kelompok eurosceptic meliputi masyarakat kelas menegah kebawah (purnakaryawan, masyarakat buruh), masyarakat dengan umur 60 keatas, serta masyarakat dengan pendidikan rendah. Keberhasilan kelompok eurosceptic dalam model sosiologi terbukti dengan besarnya jumlah pemilih referendum dari devisi kelas masyarakat diatas yang membuat pilihan untuk meninggalkan Uni Eropa. Sikap masyarakat terhadap keanggotaan Inggris di Uni Eropa dan umur merupakan dua faktor yang memiliki korelasi kuat dan saling mempengaruhi satu dan lainnya. Terdapat korelasi yang kuat antara sikap keanggotaan Inggris di Uni Eropa dan usia. Masyarakat dengan umur dibawah 25 tahun akan lebih cenderung memilih agar Inggris tetap menjadi anggota dari Uni Eropa. Sedangkan masyarakat dengan umur diatas 60 tahun akan lebih cenderung untuk memilih Inggris keluar dari Uni Eropa (Wells, 2015).

Berdasarkan polling yang diselenggarakan oleh YouGov, bahwasanya 66\% pemilih dengan umur 18-24 tahun dan 52\% dari pemilih dengan umur 25-49 tahun cenderung memilih pilihan agar Inggris menetap di Uni Eropa. Sedangkan 58\% pemilih dengan umur 50-64 tahun dan 62\% dari pemilih yang berumur $>65$ lebih cenderung membuat pilihan untuk Inggris keluar dari Uni Eropa. Mayoritas dari pemilih yang memilih untuk Inggris menetap di Uni Eropa merupakan masyarakat perkotaan dan masyarakat perkotaan. Sementara itu, pemilih yang menyumbang 


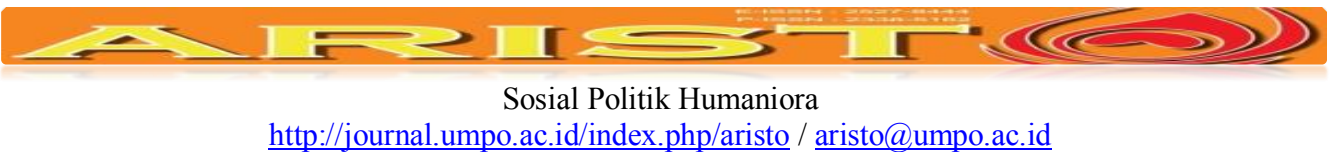

suara untuk Inggris keluar dari Uni Eropa merupakan mayoritas dari masyarakat kurang mampu dan masyarakat pedesaan (Deloy, 2016). Berdasarkan polling yang dilaksanakan oleh Lord Ashcroft, bahwa pemilih dengan usia lebih muda cenderung untuk memilih agar Inggris menetap di Uni Eropa, berbanding terbalik dengan pemilih dengan usia lebih tua cenderung untuk memilih agar Inggris keluar dari Uni Eropa (BBC, 2016). Terdapat jurang besar antara pemilih berusia muda dan pemilih yang berusia lebih tua - dengan 7 dari 10 pemilih muda mendukung Uni Eropa. Sekitar 73\% pemilih dari berusia 18 - 29 tahun menginginkan Inggris tetap menjadi bagian dari uni Eropa, sedangkan 63\% dari pemilih dengan usia diatas 60 menginginkan untuk meninggalkan Uni Eropa (Kirk, 2016).

Dari kedua polling dari lembaga terpercaya diatas yang dilakukan sebelum referendum dapat disimpulkan bahwa umur dan sikap masyarakat terhadap pemilihan dalam referendum memiliki korelasi yang kuat. Bahwa masyarakat dengan umur lebih tua cenderung untuk memilih Inggris agar keluar dari Uni Eropa. Sebaliknya, bahwa masyarakat dengan umur lebih muda memiliki kecenderungan untuk memilih agar Inggris tetap menjadi bagian dari Uni Eropa. Kedua perbedaan sikap masyarakat Inggris ini berdampak besar pada pilihan mereka pada referendum Inggris. Hasil dari referendum yang diadakan pada hari kamis 23 juni 2016, menunjukkan bahwa pemilih dari masyarakat Inggris dengan usia yang lebih tua cenderung lebih antusias untuk memilih dibandingkan dengan pemilih dari masyarakat Inggris dengan usia lebih muda (Margate, 2016). Daerah dengan pemilih tertinggi yang memilih brexit ialah daerah pesisir timur yang merupakan wilayah dengan populasi pensiun terbesar di Inggris (Dunford, 2016).Hanya dua dari tiga puluh daerah dengan mayoritas populasi masyarakat berumur 60 tahun keatas memilih Inggris menetap di Uni Eropa, yaitu South Lakeland di the North West dan South Hams di the South West. Selebihnya dua puluh delapan daerah lainnya memilih untuk brexit (Dunford, 2016). Fenomena ini kemudian menjadi kabar baik bagi kelompok eurosceptic yang mendukung Ingggris untuk keluar dari Uni Eropa.

Selain faktor usia, sikap masyarakat Inggris juga banyak dipengaruhi oleh faktor lainnya, seperti halnya faktor ekonomi yang menjadi faktor penting dalam menentukan hasil referendum Inggris 2016. Perasaan takut terhadap keberadaan imigran yang akan mengganggu penghasilan mereka menjadi salah satu faktor yang mempengaruhi sikap masyarakat ini. Tidak terbatas pada faktor usia dan latar belakang ekonomi, faktor pendidikan juga menjadi faktor terpenting yang mempengaruhi sikap para pemilih dalam referendum. Menurut Gylfi Zoega, profesor ekonomi di 


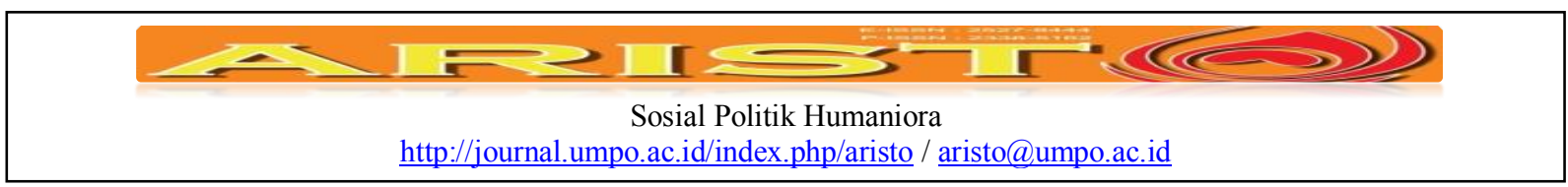

universitas iceland, bahwa masyarakat dengan usia lebih tua dan berpenghasilan rendah cenderung untuk tidak menyukai imigran dan takut pada pengaruh Uni Eropa. Ketakutan ini selanjutnya berpengaruh besar pada sikap mereka dimasa referendum untuk memilih brexit. Sikap masyarakat Inggris yang demikian dikarenakan perasaan rentan mereka terhadap para imigran yang datang dari negara-negara Uni Eropa lainnya. Namun, bukti empiris menunjukkan bahwa pengaruh merugikan dari imigran terhadap pasar tenaga kerja relatif lemah, walaupun ada beberapa bukti pada pekerja dengan keterampilan rendah, bahwa kenaikan 10\% dari proporsi imigran berdampak pada penurunan upah sebesar 1,8\%.

Korelasi antara imigran dan penurunan pendapatan masyarakat Inggris menjadi ketakutan yang berlebihan bagi beberapa masyarakat Inggris terhadap imigran, dan kemudian menjadi perdebatan publik dan kemudian mempengaruhi sikap masyarakat untuk meninggalkan Uni Eropa. Hal ini diakibatkan oleh karena masyarakat menganggap bahwa jumlah besaran efek dari imigran jauh lebih besar daripada kenyataannya. Berdasarkan hasil polling oleh institusi Mori yang diterbitkan pada tanggal 9 Juni 2016 (dua minggu sebelum referendum dilaksanakan), dapat disimpulkan bahwa responden berpikir jumlah rata-rata warga Uni Eropa di Inggris berkisar sekitar 15\% dari total populasi Inggris sekitar 10,5 juta orang, sedangkan angka sebenarnya adalah 5\% atau sekitar 3,5 juta orang (Zoega, 2016). Hal ini menjelaskan bahwa masyarakat Inggris menganggap imigran telah terlalu banyak berdomisili di Inggris sehingga merebut banyak lapangan pekerjaan mereka terkhusus bagi masyarakat menengah kebawah.

Tingkatan pendidikan dan klasifikasi kelas sosial merupakan dua faktor yang berpengaruh besar pada referendum Inggris, sementara itu, masyarakat kelas menegah kebawah Inggris (buruh dan pegawai pensiun) lebih cenderung memilih agar Inggris keluar dari Uni Eropa. Berdasarkan polling, mayoritas masyarakat lulusan dari universitas cenderung menginginkan agar Inggris tetap menjadi anggota dari di Uni Eropa, sedangkan mereka lulusan dari sekolah menegah dan sederajat lebih cenderung menginginkan agar Inggris keluar dari Uni Eropa. Survey dari polling ini menjadi pola yang berbanding lurus dengan hasil referendum, mayoritas pemilih bremain merupakan masyarakat dengan pendidikan tinggi, sedangkan sebaliknya mayoritas masyarakat pemilih brexit merupakan masyarakat dengan pendidikan rendah (Dunford, 2016). Daerah dengan jumlah pemilih terbesar tercatat berada di daerah yang memiliki purnakaryawan melebihi dari seperempat dari jumlah populasi. Dan mayoritas dari masyarakat ini memiliki kecenderungan untuk meninggalkan Uni Eropa (Margate, 2016). Termasuk daerah 


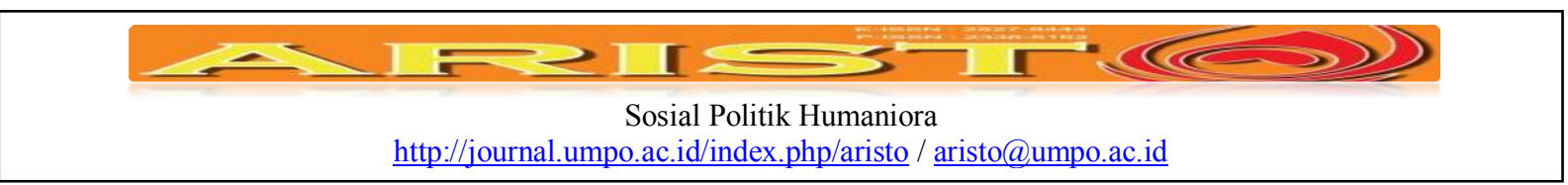

Blaenau Gwent di Wales merupakan daerah yang memiliki pupolasi masyarakat buruh relatif tinggi di Inggris. Sekitar 62\% dari masyarakat daerah ini menjadi pemilih yang memilih untuk brexit. Hanya tiga dari lima puluh daerah dengan latar belakang populasi kelas menegah kebawah menjadi pemilih yang memilih untuk bremain. Leicester, Liverpool dan Newham di London memberikan hasil statistik yang anomali karena mereka merupakan kota besar dengan populasi usia muda yang tinggi (Dunford, 2016).

Secara garis besar, pemilih yang pro-Uni Eropa cenderung memiliki pendapatan rumah tangga yang lebih tinggi dibandingkan pemilih yang mendukung kontra-Uni Eropa. Sekitar 37\% dari pemilih pro-Uni Eropa merupakan mereka yang memiliki gelar sarjana, sebaliknya hanya $15 \%$ dari pemilih kontra-Uni Eropa yang memiliki gelar sarjana. Faktor yang menyebabkan perbedaan diatas secara garis besar bersumber dari perbedaan usia. Pada masa lalu, hanya sebagian kecil masyarakat yang menempuh gelar sarjana dan dengan biaya kehidupan yang relatif lebih murah. Namun secara singkat, masyarakat dengan usia muda, kelas menegah keatas, dan sarjana akan cenderung menjadi pemilih yang pro-Uni Eropa, sedangkan masyarakat dengan usia tua, kelas pekerja atau buruh, menengah keatas dan mereka yang berpendidikan rendah akan cenderung menjadi pemilih yang kontra-uni Eropa (Wells, 2015).

Pola pemilihan berdasarkan daerah dalam referendum, merefleksikan keterkaitannya dengan faktor-faktor seperti ekonomi dan demografi. Terlebih terkait prilaku, sikap dan pandangan masyarakat Inggris yang memiliki tetangga seorang imigran, ketakutan terhadap pengaruh imigran, ketakutan terhadap kehilangan identitas nasional Inggris, dan bahkan ketakutan terhadap kehilangan pekerjaan. Daerah bagian Inggris dengan pendapatan perkapita rendah, daerah dengan proporsi buruh dengan pendidikan rendah dan daerah dengan proporsi demografi masyarakat diatas 65 tahun akan lebih cenderung untuk menunjukkan skeptikalnya terhadap Uni Eropa dan para imigran. Terkecuali negara bagian seperti Scotlandia dan Irlandia Utara, dimana masyarakat didalamnya memiliki respon yang positif terhadap keberadaan Uni Eropa dan para Imigran, sehingga mereka tidak bisa dijelaskan dengan faktor ekonomi tersebut (Zoega, 2016). Sebelum pelaksanaan referendum, telah banyak polling yang diadakan terkait bagaimana korelasi antara perbedaan demografi penduduk terhadap perbedaan pendapat dalam referendum. Hasil referendum berbanding lurus dengan polling ini. Hasil referendum menunjukkan bahwa mayoritas masyarakat disebuah daerah memilih berdasarkan latar belakang yang mereka miliki, baik perbedaan kelas sosial dalam masyarakat, perbedaan umur hingga 


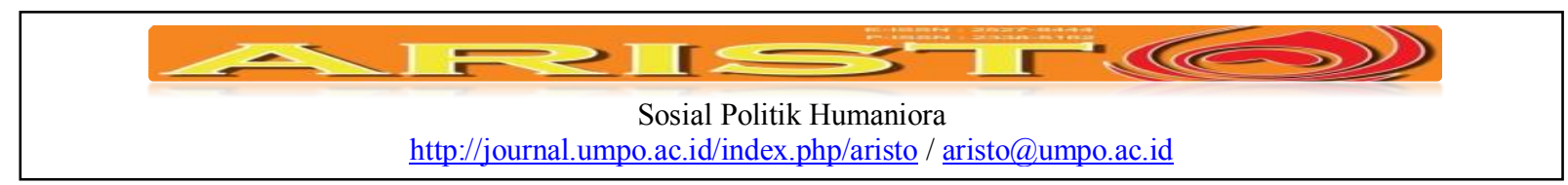

perbedaan pendidikan. Umur, pendidikan, status kelas sosial dalam masyarakat menjadi indikasi penting dalam dalam pelaksanaan referendum (Dunford, 2016).

\section{Model Dominasi Ideologi : Kebangkitan Eurosceptic di Tengah Masyarakat Inggris}

Kebangkitan paham eurosceptic di tengah-tengah masyarakat Inggris menjadi salah satu faktor besar yang mempengaruhi hasil referendum Inggris 2016. Tidak dipungkiri bahwa eurosceptic telah merambah ke dalam masyarakat luas Inggris. Meluasnya pemahaman sceptik dalam masyarakat Inggris terhadap Uni Eropa kemudian berdampak pada sikap masyarakat dalam menentukan pilihan mereka dalam referendum Inggris 2016. Maka, dengan bertambahnya masyarakat eurosceptic di Inggris, bertambah pula pemililh referendum yang memilih Inggris untuk keluar dari Uni Eropa.

Istilah eurosceptic pertama kali muncul pada 11 November tahun 1985 dalam koran Inggris, The Times, untuk menggambarkan oposisi skeptis terhadap Uni Eropa dan kebijakankebijakan dari Uni Eropa, istilah ini menjadi lebih fleksibel apabila dibandingkan dengan istilah euro-phobia ataupun istilah anti-Europeanism (Mehlika Ozlem Ultan, 2015). Eurosceptic hampir terdapat di setiap kalangan terutama dikalangan para aktor politikus, dan paham ini pun hampir terdapat diseluruh negara anggota Uni Eropa, hanya saja dengan level dan jumlah yang berbeda antara satu negara dan negara lainnya(Association of Accredited Public Policy Advocates to the European Union, 2013)

Paham eurosceptic pertama kali muncul dalam masyarakat Inggris ialah pada masa awal Inggris akan menjadi anggota resmi dari EEC atau sekarang disebut Uni Eropa. Pada saat itu tepatnya tahun 1975, juga diselenggarakan referendum yang akan memutuskan apakah Inggris akan benar-benar menjadi bagian dari EEC ataupun sebaliknya batal menjadi anggota dari EEC. Pada masa awal kemunculannya, paham ini tidak mendominasi masyarakat Inggris seperti saat ini. Dengan bukti bahwa hasil dari referendum 1975 menunujukkan bahwa mayoritas pemilih memilih untuk bergabung bersama EEC. Perjalanan Inggris bersama Uni Eropa sangat jarang berjalan dengan mulus sebagaimana proses bergabungnya Inggris kedalam EEC. Seiring berjalannya waktu tidak jarang politikus Inggris berubah menjadi sceptis terhadap Uni Eropa. Sebagaimana yang dialami oleh Margaret Thatcher, berawal menjadi kelompok yang mendukung bergabungnya Inggris kedalam Uni Eropa, namun ketika menjabat menjadi Perdana Menteri Ingris tidak jarang mengeluarkan pendapat yang skeptis terhadap Uni Eropa. Tidak 


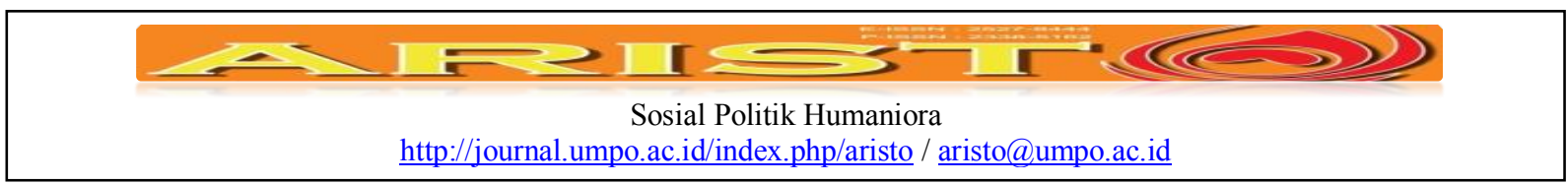

hanya bertahan pada Margaret Thatcher, namun paham eurosceptic terus menjamah kedalam masyarakat Inggris.

Ratifikasi perjanjian mastrik pada tahun 1992 menjadi pemicu besar terhadap kebangkitan kelompok eurosceptic. Tidak terbatas pada Inggris, bahkan jauh lebih luas hingga pada negaranegara anggota Uni Eropa lainnya. Penerapan kebijakan baru Uni Eropa yang memperluas wilayah kerjasama hingga ke area politik berdampak pada menurunnya legitimasi masyarakat Uni Eropa terhadap Uni Eropa. Hal ini berdasarkan hasil dari survey yang dilaksanakan oleh Eurobarometer pada 13 Oktober dan 9 November 1993. Selanjutnya meluasnya paham eurosceptic dalam masyarakat Inggris dapat dianalisa dari banyaknya penggunaan isu eurosceptic sebagai alat kemenangan dalam perpolitikan Inggris. Dimulai dengan kemenangan Ducan dalam memperebutkan kursi sebagai pemimpin partai konservatif pada tahun 2001. Kemenangan UKIP dalam pemilu Eropa pada tahun 2004 dan 2009 pun tidak terlepas dari peran isu eurosceptic. Dan bukti terbaru sebelum referendum Inggris dilaksanakan ialah kemenangan partai Konservatif dalam pemilu Inggris tahun2015. Dengan mengedepankan isu eurosceptic, David Cameron berjanji akan mengadakan perbincangan ulang terkait keanggotaan Inggris di Uni Eropa dengan seluruh kepala negara anggota Uni Eropa dan selanjutnya berjanji akan mengadakan referendum terkait keanggotaan Inggris di Uni Eropa.

Sejumlah paparan diatas menjelaskan bahwa kemenangan kelompok eurosceptic dalam referendum Inggris 2016 berkaitan kuat dengan meluasnya pemahaman eurosceptic dalam masyarakat Inggris. Hasil referendum Inggris 2016 dengan kemenangan kelompok eurosceptic, merefleksikan besarnya skeptisme masyarakat Inggris terhadap Uni Eropa. Kemudian secara tidak langsung menjadi pembuktian bahwa paham eurosceptic terus meluas dalam maysarakat Inggris sejak pertama kemunculannya di Inggris.

\section{Model Identifikasi Partai: Pengaruh Partai UKIP Dalam Referendum}

Partai UKIP memiliki peran besar dalam kemenangan kelompok eurosceptic pada referendum Inggris 2016. UKIP tidak memiliki sejarah besar dibandingkan dengan partai Buruh dan partai Konservatif dalam sejarah perpolitikan Inggris. Namun, semenjak menjadi partai eurosceptic, UKIP mulai menjadi partai yang mendominasi dalam pemilihan umum Inggris. Semenjak beberapa tahun terakhir, UKIP telah mulai mengumpulkan masyarakat Inggris untuk mengusung Inggris keluar dari Uni Eropa. Disaat mayoritas partai politik Inggris terpecah dalam 


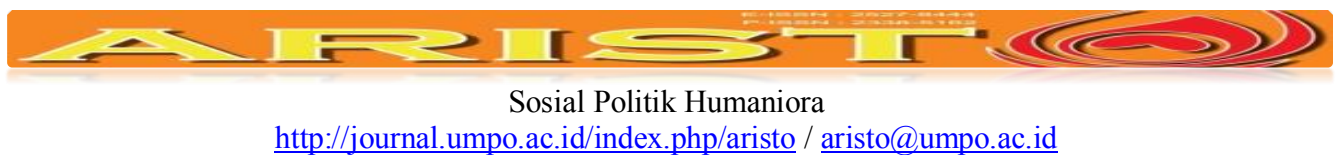

menghadapi referendum Inggris, partai UKIP tetap dengan dominasi mendukung untuk Inggris meninggalkan Uni Eropa. Tahun 2013 menjadi menjadi batu loncatan pertama bagi partai UKIP dalam dunia perpolitikan Inggris. Pada 3 mei 2013, hasil pemilu lokal Inggris menunjukkan bahwa UKIP berhasil memenangkan seperempat dari jumlah total suara, dan menempati posisi ketiga dari seluruh partai setelah partai Buruh dan Konservatif. Walapupun masih belum mampu mengalahkan suara dari partai Buruh dan Konservatif, pencapaian ini menjadi sejarah besar dalam perpolitikan Inggris. Dengan mengusung paham euroskeptic - menggagas Inggris untuk keluar dari Uni Eropa - dalam pemilu lokal Inggris, UKIP menjadi oposisi tunggal terhadap partai besar di Inggris (BURNS, 2013).

Pertama dalam sejarah modern Inggris, pemilihan umum nasional Inggris 2014 untuk pertama kali berhasil dimenangkan oleh selain partai besar Konservatif dan Buruh. Nigel Farage, dengan mengusung slogan sederhana "membawa Inggris keluar dari Uni Eropa" berhasil membawa UKIP kepuncak kemenangan dalam pemilihan umum untuk Parlemen Eropa 2014. Peristiwa ini menjadi kemenangan partai eurosceptic pertama dalam sejarah modern Inggris dengan mengalahkan partai besar Buruh dan Konservatif (Watt, 2016). Dua kemenangan gemilang UKIP diatas menggambarkan bahwa partai ini telah mendapatkan banyak dukungan dari masyarakat Inggris setelah mengusung isu eurosceptic dalam pemilu yang ada. Dua kemenangan diatas menjadi modal besar bagi partai UKIP dalam memperjuangkan kelompok eurosceptic pada referendum Inggris 2016. Ditambah dengan Nigel Farage, pemimpin dari partai UKIP memegang peranan penting dalam kampanye untuk memperjuangkan brexit. Hal ini berdampak terhadap masyarakat Inggris yang memiliki keterikatan secara psikologi terhadap partai UKIP makin teguh untuk menjadi pemilih referendum yang mendukung untuk Inggris keluar dari Uni Eropa (Dunford, 2016). Lembaga survey YouGov mengadakan poling terkait bagaimana kecenderungan pemilih dari partai mayor di Inggris dalam menghadapi referendum Inggris 2016. Hasil poling menunjukkan bahwa partai Konservatif terpecah menjadi dua kubu, dan partai Buruh menunjukkan hasil semisal namun dengan dominasi memilih untuk menetap di Uni Eropa. Hal yang mengejutkan tertuju pada pemilih yang berasal dari partai UKIP, hasil menunjukkan bahwa Uni Eropa sama sekali bukan merupakan hal yang populer dalam pandangan pemilih dari partai ini, hasil poling menunjukkan sekitar 97\% menginginkan untuk Inggris keluar dari Uni Eropa (Kirk, 2016). 


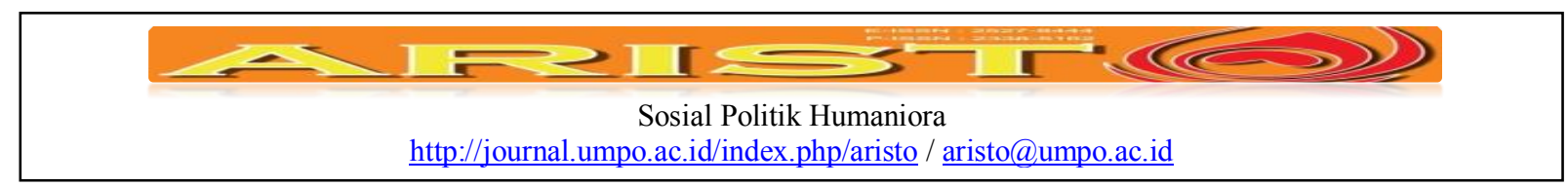

\section{Strategi Kampanye Kelompok Eurosceptic}

Hasil poling pada tahap awal kampanye referendum sering memberikan indikasi yang sangat miskin terhadap hasil aktual suara referendum. Pada masa awal kampanye sikap masyarakat terhadap Uni Eropa jauh lebih lunak dibandingkan suara dalam referendum. Banyak hal yang mungkin terjadi saat kampanye berlangsung, dan besar kemungkinan berimplikasi pada perubahan sikap masyarakat terhadap Uni Eropa. Strategi kampanye menjadi senjata berharga bagi setiap kubu dalam referendum, baik kubu Remain maupun Leave. Strategi kampenye yang baik berimplikasi besar pada kesuksesan dalam sebuah pemilihan. Dalam bagian ini penulis akan mengulas terkait strategi yang digunakan oleh kelompok eurosceptic dalam memenangkan referendum. Adapun beberapa strategi kampanye yang digunakan oleh kelompok eurosceptic dimasa kampanye ialah; pertama, Project Fear dan Hubungan Emosional; kedua, Emotional Connettion; ketiga, Pengaruh dari Publik Figur.

\section{Project Fear}

Project Fear adalah sebuah julukan terhadap kampanye yang direalisasikan pada masa kampenye dalam referendum Inggris dan Scotlandia. Kampanye ini ditujukan agar Scotland tidak meninggalkan Inggris. Termasuk didalamnya peringatan dari George Osborne, diperkuat oleh Ed Balls dari partai Buruh, dan Danny Alexander dari partai Demokrasi Liberal, bahwa Scotland tidak bisa mengandalkan kesepakatan serikat mata uang jika mereka memilih untuk merdeka (Mcsmith, 2016). Menjadi sebuah sejarah besar bagi Inggris terkait hasil referendum Inggris 2016. Hasil referendum menunjukkan besar dukungan masyarakat untuk keluar dari Uni Eropa. Menurut sejumlah pakar hal ini mejelaskan bahwa sebagian besar masyarakat lebih menentukan pilihan berdasarkan dorongan kuat dari naluri atau instink daripada perhitungan yang dingin. Der Spiegel, yaitu salah satu lembaga publikasi terkemuka di Jerman, mengamukakan bahwa keputusan ini didasarkan pada perasaan cepat ketimbang berdasarkan alasan yang matang (Ruryk, 2016).

Project Fear merupakan sebuah strategi yang dianggap strategis dan sering digunakan oleh kedua belah pihak, baik Remain maupun Leave. Kedua kampanye mengklaim satu sama lain sedang menjalankan Project Fear, sementara mereka masing-masing selalu menggunakan bahasa yang hiperbola hingga akhir kampanye. Alasan yang melatar belakangi kemenangan Project Fear yang diusung oleh kelompok eurosceptic ialah karena mereka menggambarkan kampenye 


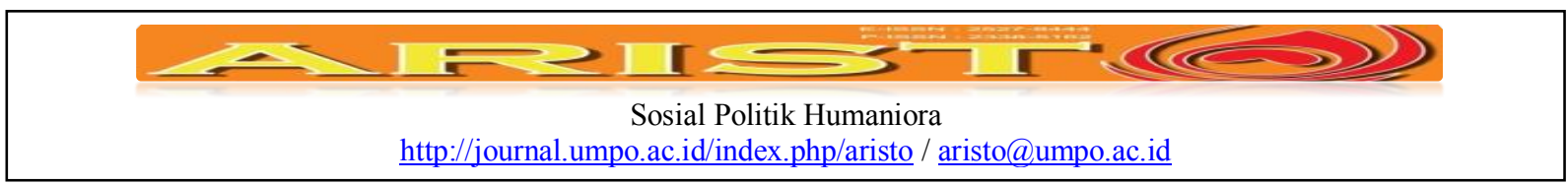

mereka dengan bahasa yang familiar pada masyarakat umum, sehingga mampu memasuki ruang asumsi pribadi masyarakat. Topik sasaran utama dari kampanye Remain yaitu terkait dampak ekonomi, mendapat klaim bahwa terlalu jauh dari keseharian masyarakat pada umumnya. Menurut Ipsos Mori, salah satu lembaga riset terkemuka di Inggris, mengemukakan bahwa topik yang diangkat oleh kelompok eurosceptic yaitu terkait imigrasi jauh lebih banyak mempengaruhi masyarakat apabila dibandingan dengan topik ekonomi yang diusung oleh kelompok bremain. Peningkatan drastis terkait sentimen anti-imigrasi menjadi tantangan besar bagi kelompok bremain (Farshori, 2016).

Kubu Remain mendasarkan seluruh kampenye pada asumsi bahwa kalah atau menang dalam referendum akan berimplikasi pada ekonomi. Kubu Remain percaya bahwa masyarakat Inggris menyadari pekerjaan, keamanan dan kemakmuran mereka akan berada dalam garis aman, apabila mereka memilih untuk bergabung bersama Uni Eropa. Namun mereka meremehkan faktor emosional masyarakat terhadap kedaulatan negara, sehingga salah dalam memperhitungkannya. kubu Leave bermain secara cerdas dalam kampanye dengan memanfaatkan keresahan masyarakat terhadap Uni Eropa. Dengan menggagas pesan dengan nada "Take Back Control", mereka terbukti mampu mengeluarkan perasaan patriotisme dalam masyarakat Inggris (Beattie, 2016). Secara gari besar, kemenangan Project Fear dari kelompok eurosceptic dilatar belakangi oleh bebagai faktor. Diantaranya penggunaan bahasa komunikasi yang lebih familiar terhadap masyarakat umum menjadi poin penting yang mampu mempengaruhi emosional pribadi masyarakat umum. Kemampuan dalam mengangkat isu imigrasi, kelompok eurosceptic mampu mempengaruhi masyarakat umum lebih mudah oleh karena telah terjadi dalam keseharian mereka. Brexit mampu mempengaruhi rasa patriotisme masyarakat, melalui slogan sederhana yang mudah dipahami dan mengandung makna yang kuat.

\section{"Emotional Connection"}

Pasca referendum, Arron Bank, salah satu milioner asal Inggris dan salah satu pencetus kampanye Leave.EU, menyatakan kepada pihak The Guardian bahwa "Kami menggunakan gaya pendekatan milik Amerika yang melihat bahwa fakta tidak akan berimplikasi besar dalam kampanye." 'Sebagaimana kubu 'Bremain' yang selalu menyatakan fakta-fakta, itu semua tidak bekerja. Kalian harus berinteraksi dengan masyarakat menggunakan pendekatan emosional." (Worley, 2016). Dari pernyataan Arron diatas dapat disimpulkan bahwa Leave.EU mendapatkan 


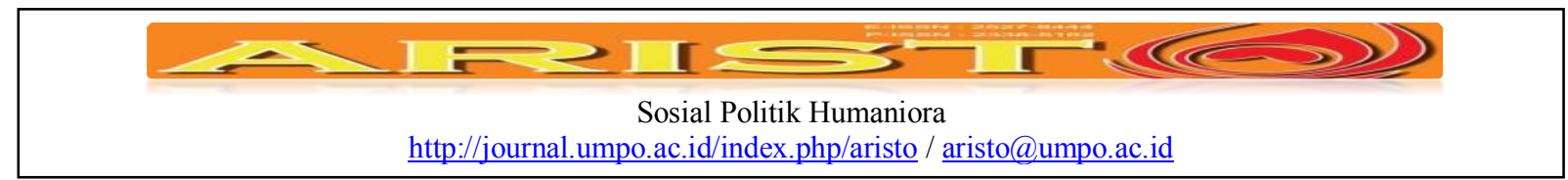

pengaruh yang besar dari Donald Trump dalam pembuatan strategi kampenye pada masa referendum Inggris.

Menjalin hubungan emosional dengan masyarakat pemilih menjadi kunci kemenangan utama bagi kelompok Leave.EU. Hubungan emosional yang diciptakan oleh kelompok ini diterima secara luas dalam masyarakat umum Inggris terutama dalam isu imigrasi. Hubungan emosional ini tersampaikan dengan baik pada masyarakat umum Inggris, terkhusus bagi masyarakat kelas menegah kebawah, purnakaryawan, masyarakat usia 60 tahun keatas, dan masyarakat berpendidikan rendah. Sementara bagi masyarakat perkotaan dan masyarakat dengan pendidikan tinggi, pendekatan kelompok Leave.EU ini tidak berjalan semaksimal sebagaimana bagi kelas-kelas masyarakat sebelumnya. Sebagaimana yang disampaikan oleh Daniel Korski (wakil ketua dari unit kebijakan pemerintahan pada masa David Cameron) dalam tulisannya pada laman Politico.eu ; 'Kubu 'Vote Leave' dengan bangga menafikan segala fakta dan membangun citra tokoh mereka." "Para pemilih tidak mempercayai kami ketika kami berikan fakta bahwa meninggalkan Uni Eropa berarti membuat pemasukan rata-rata rumah tangga memburuk sebesar $£ 4,300$. Namun mereka mempercayai argumen kubu 'Vote Leave’ bahwa Inggris mengirim £350 juta per minggu untuk Uni Eropa." Hal ini menjadi bukti keberhasilan dari strategi "emotional connetion" yang diterapkan oleh kelompok Leave.EU dalam masa kampanye. Dengan bukti diatas bahwa masyarakat lebih mementingkan emosional mereka ketimbang fakta yang ada (Korski, 2016).

\section{Pengaruh Publik Figur}

Boris Johnson dan Michael Gove merupakan dua member dari kabinet David Cameron yang menunjukkan pengaruh besar bagi kampanye brexit. Keberadaan kedua tokoh ini menjadi booter besar bagi kampanye brexit. Boris Johnson menjadi sosok yang langsung turun ke dalam masyarakat dengan menggunakan bus Vote Leave mengelilingi kota-kota yang ada di Inggris. Sementara Michael Gove memerankan posisinya sebagai publik figur yang mewakili Brexit dalam acara-acara TV untuk mempromosikan brexit, terkhusus dalam Sky News dan the BBC (BBC, 2016).

Sebelumnya Boris merupakan rival dari David Cameron dalam memperebutkan kursi kepemimpinan dalam partai Konservatif. Boris Johnson merupakan tokoh brexit yang sangat dominan dengan segala stetmennya yang profokatif, terbukti dengan berbagai pernyataan yang ia 


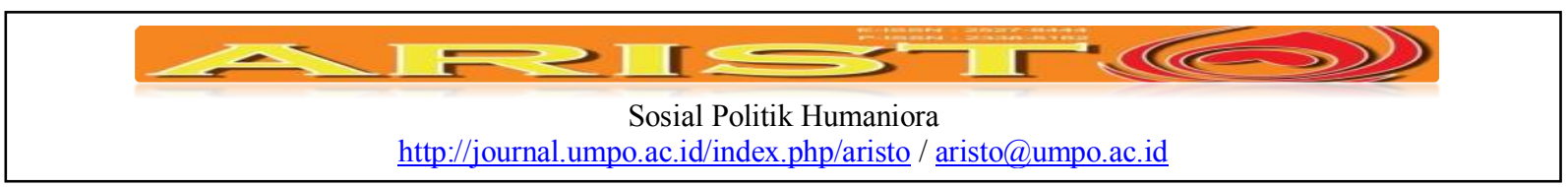

lontarkan pada masa kampanye. Pada tanggal 9 mei, Boris menyatakan pada The Telegraph, "Napoleon, Hitler, various people tried this out, and it ends tragically. The EU is an attempt to do this by different methods." Dan beberapa hari selanjutnya Boris kembali menyatakan : "It was time for the U.K. to break away from the failing and dysfunctional EU system" (Calamur, 2016). Semua pernyataan Boris diatas dapat diterjemahkan bahwa ia menganggap Uni Eropa merupakan sebuah ancaman besar yang akan menjajah Inggris jika Inggris tetap menjadi anggota dari Uni Eropa.

Tidak berbeda dengan Nigel Farage, yaitu merupakan sosok dari eurosceptic Inggris, yang semenjak beberapa tahun terakhir sering memenangkan bayak pemilihan umum abik lokal maupun nasional dengan menggagas misi-misi dari euroceptic. Sebagai keahliannya Nigel sering melakukan pekerjaannya sendiri dan tidak jarang menimbulkan kontroversi dalam masyarakat. Namun walaudemikian, Sebagai pemimpin dari partai UKIP, Nigel memainkan peranan peting dalam memotovasi para masyarakat pendukung dari partainya untuk memilih brexit. Terbukti dengan polling yang diadakan oleh YouGov, menunjukkan bahwa semua partai terpecah ketika menghadapi referendum Inggris, kecuali Partai UKIP. Sekitar 97\% dari pendukung UKIP menyatakan akan memilih untuk meninggalkan Uni Eropa dalam referendum.

Pada kubu brexit, masyarakat akan mendengarkan apapun instruksi yang datang dari para pemimpin mereka. Meskipun secara faktual tidak akurat, banyak masyarakat mempercayai bahwa Turky sedang menunggu keputusan Inggris untuk tetap bergabung dalam Uni Eropa. Mereka lebih mempercayai perkataan para pemimpin dalam Brexit ketimbang melihat fakta yang ada. Masyarakat umum lebih mempercayai sosok yang mereka kenal melebihi instruksi dari sebuah institusi yang tidak mereka kenal. Sekitas 46\% masyarakat umum tidak menganggap adanya ancaman yang akan mereka dapatkan apabila memilih brexit. Suatu yang sangat krusial bahwa masyarakat tidak lagi melihat sosok peminpin dalam diri David Cameron. Sebagian besar masyarakat umum menilai bahwa Cameron telah berpaling dari ketetapannya yang pernah dia buat. Pada awalnya Cameron dengan sangat meyakinkan menggagas pengadaan referendum, namun pada pelaksanaannya lebih mendukung untuk menetap dalam Uni Eropa (Farshori, 2016).

\section{Kesimpulan}

Kemenangan kelompok eurosceptic dalam referendum menjadi sebuah kontradiktif terhadap kesimpulan dari banyak analisis dan polling yang beredar diawal referendum. 


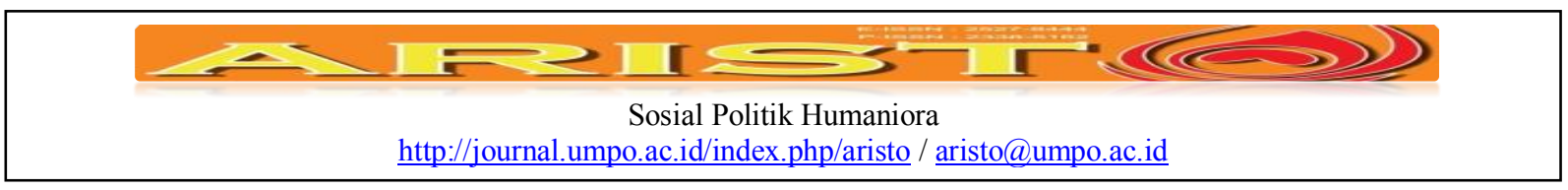

Kemenangan ini merupakan suatu hal yang sudah terencana dan terkonsep dengan baik. Dari pendekatan Theory Voting Behaviour, menjelaskan bahwa kelompok eurosceptic menerapkan tiga model dari empat model yang ada. Pertama, model sosiologi dimana kelompok eurosceptic berusaha mempengaruhi masyarakat Inggris melalui latar belakang kelas sosial masyarakat. Kelas sosial yang menjadi fokus dari kelompok eurosceptic mencangkup masyarakat kelas menengah kebawah, masyarakat dengan umur 60 tahun keatas, pekerja buruh, dan masyarakat dengan pendidikan rendah. Kedua, model ideologi dominan yangmana kelompok eurosceptic berusaha mempengaruhi hasil referendum dengan menggunakan kebangkitan dan penyebaran paham eurosceptic yang meluas dalam masyarakat Inggris saat ini. Ketiga, model identifikasi partai yaitu dengan memanfaatkan keterikatan sekelompok masyarakat pada suatu partai, untuk menjadi bagian dari masyarakat yang memilih agar Inggris keluar dari keanggotaan Uni Eropa. Sedangkan model keempat, model pilihan rasional, penulis tidak melihat pengaruh signifikan model ini dalam penilitian ini. Oleh karnanya, model ini tidak masuk dalam pembahasan dalam artikel ini. Kemenangan kelompok eurosceptic pun tidak terlepas dari keberhasilan dalam menjalankan strategi kampenye. Setidaknya kelompok eurosceptic memiliki tiga strategi dalam referendum ini. Pertama, strategi 'Project Fear' yaitu suatu strategi dengan membuat ketakutan dalam masyarakat Inggris, sehingga masyarakat menilai bahwa keluar dari Uni Eropa merupakan opsi terbaik. Strategi kedua ialah 'Emotional Connection' yaitu strategi yang memanfaatkan hubungan emosional masyarakat dalam menjalankan kampanye kelompok eurosceptic. Masyarakat akhirnya cenderung mengedepankan instink mereka melebihi menggunakan alasan yang ada. Strategi ketiga yaitu 'Pengaruh dari Publik Figur' yaitu sebuah strategi dengan menggunakan peran tokoh terkemuka yang ada di Inggris. Tokoh yang sudah mendapat posisi dalam masyarakat akan lebih mudah diterima argumen mereka ketimbang mereka yang tidak memiliki posisi dalam masyarakat.

\section{Daftar Pustaka}

Arzheimer, K. (2008). Voter Behaviour. Retrieved from kai-arzheimer.com: http://www.kaiarzheimer.com/paper/voter-behaviour/

Association of Accredited Public Policy Advocates to the European Union. (2013, september 29). WHO ARE THE EUROSCEPTICS ? Retrieved from AALEP: http://www.aalep.eu/who-are-eurosceptics 


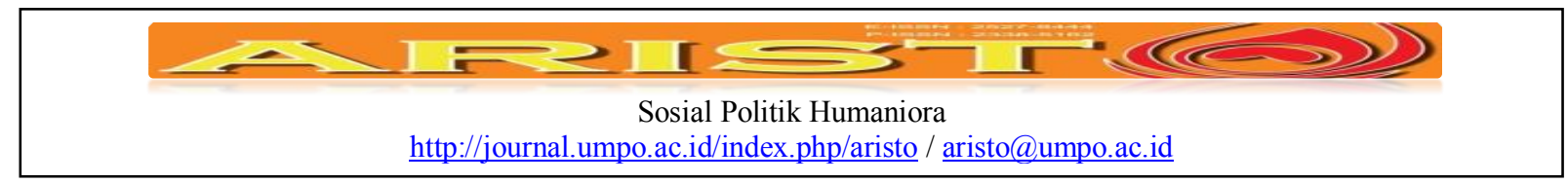

BBC. (2015, Juni 10). Parlemen Inggris setujui referendum Uni Eropa. Retrieved from bbc.com: http://www.bbc.com/indonesia/dunia/2015/06/150609_dunia_inggris_eu_referendum

BBC. (2016, Juni 24). Eight reasons Leave won the UK's referendum on the EU. Retrieved from BBC: http://www.bbc.com/news/uk-politics-eu-referendum-36574526

BBC. (2016, Juni 24). EU referendum: The result in maps and charts. Retrieved from BBC.com: http://www.bbc.com/news/uk-politics-36616028

Beattie, J. (2016, Juni 24). Leave won the EU referendum because the country voted with its heart rather than its head. Retrieved from Mirror.co.uk: http://www.mirror.co.uk/news/uk-news/leave-won-eu-referendum-because-8277471

BURNS, J. F. (2013, mei 3). Insurgent Party in Britain Gains in Popular Support. Retrieved from The New York Times: http://www.nytimes.com/2013/05/04/world/europe/unitedkingdom-independence-party-gains-in-local-vote.html

Calamur, K. (2016, Juni 23). The 'Brexit' Campaign: A Cheat Sheet. Retrieved from The Atlantic: $\quad$ http://www.theatlantic.com/international/archive/2016/06/uk-brexitguide/482730/

Deloy, C. (2016). 43 years after their accession Britons decide to leave the European Union. FONDATION ROBERT SCHUMAN.

Dunford, A. K. (2016, Juni 27). EU referendum: How the results compare to the UK's educated, old and immigrant populations. Retrieved from Telegraph.co.uk: http://www.telegraph.co.uk/news/2016/06/24/eu-referendum-how-the-results-compareto-the-uks-educated-old-an/

Dunford, A. K. (2016, Juni 27). EU referendum: How the results compare to the UK's educated, old and immigrant populations. Retrieved from The Telegraph: http://www.telegraph.co.uk/news/2016/06/24/eu-referendum-how-the-results-compareto-the-uks-educated-old-an/

Eckert, V. T.-A. (2014). Campaign Handbook A user's guide to campaigning. Belgium: the Green European Foundation. Retrieved from campaignhandbook.gef.eu: http://campaignhandbook.gef.eu/planning-strategically/

Farshori, A. (2016, Agustus 30). How The Battle Of Campaign Strategy Gave Us Brexit. Retrieved from Huffington Post: www.huffingtonpost.co.uk/abbas-farshori/how-thebattle-of-campaig_b_11707680.html 


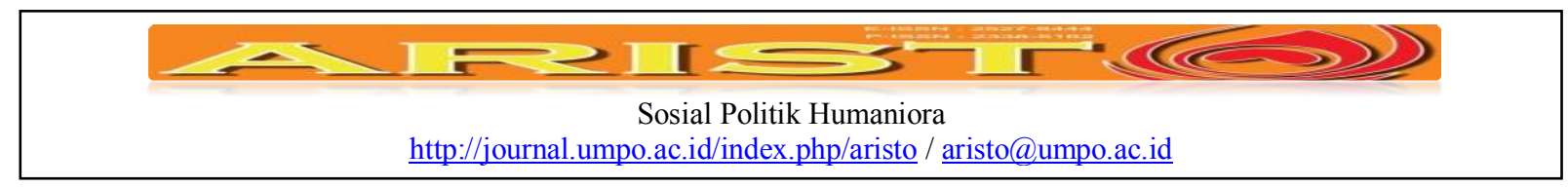

Farshori, A. (2016, Agustus 30). How The Battle Of Campaign Strategy Gave Us Brexit. Retrieved from Huffington Post: http://www.huffingtonpost.co.uk/abbas-farshori/howthe-battle-of-campaig_b 11707680.html

Fishwick, C. (2016, februari 24). Brexit or Bremain? Share your pro- or anti-EU arguments. Retrieved from theguardian.com: https://www.theguardian.com/politics/2016/feb/24/brexit-or-bremain-share-your-pro-oranti-eu-arguments.

Heywood, A. (2013). Politics. Basingstoke: Palgrave.

KBBI. (2016). strategi. Retrieved from Kamus Besar Bahasa Indonesia (KBBI): http://kbbi.web.id/strategi

Kirk, A. (2016, Juni 22). EU referendum: Which type of person wants to leave, and who will be voting to remain? Retrieved from Telegraph.co.uk: http://www.telegraph.co.uk/news/2016/06/22/eu-referendum-which-type-of-personwants-to-leave-and-who-will-b/

Kirk, A. (2016, Juni 22). EU referendum: Which type of person wants to leave, and who will be voting to remain? Retrieved from The Telegraph: http://www.telegraph.co.uk/news/2016/06/22/eu-referendum-which-type-of-personwants-to-leave-and-who-will-b/

Korski, D. (2016, Oktober 20). Why we lost the Brexit vote. Retrieved from Politico.eu: http://www.politico.eu/article/why-we-lost-the-brexit-vote-former-uk-prime-ministerdavid-cameron/

Margate, S. S. (2016, Juni 24). The U.K.'s Old Decided for the Young in the Brexit Vote. Retrieved from Time.com: http://time.com/4381878/brexit-generation-gap-olderyounger-voters/

Mcsmith, A. (2016, Juni 24). Brexit: Project Fear had reason on its side, but anti-experts caught public mood. Retrieved from The Independent: http://www.independent.co.uk/news/uk/politics/brexit-project-fear-had-reason-on-itsside-but-anti-experts-caught-public-mood-a7101841.html

Mehlika Ozlem Ultan, S. O. (2015). Euroscepticism In The European Union. International Journal of Social Sciences, 52. 


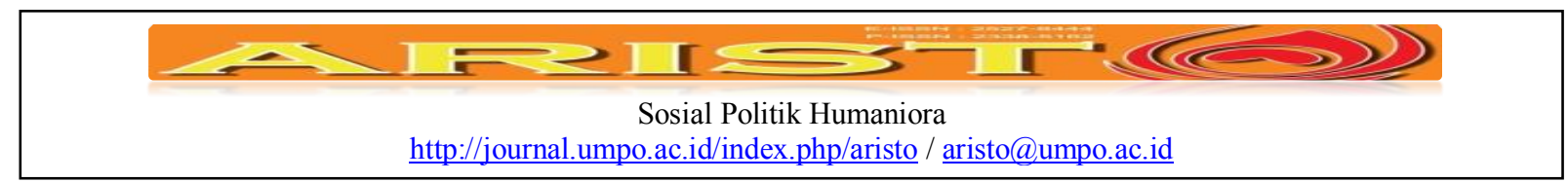

merriam-webster. (2016, november 3). dictionary. Retrieved from Merriam-Webster.com: http://www.merriam-webster.com/about-us

Morris, S. (2016, 2 26). David Cameron: EU referendum is the 'people's choice'. Retrieved from The Guardian: http://www.theguardian.com/politics/2016/feb/26/david-cameron-eureferendum-peoples-choice-uk

Nickols, F. (2016). strategy, definition and meaning. Retrieved from www.nickols.us: http://www.nickols.us/strategy_definitions.pdf

oxforddictionaries.com. (2016, november 3). definition. Retrieved from oxforddictionaries.com: https://en.oxforddictionaries.com/definition/vote

Rowena Mason, F. S. (2016, februari 23). How will your MP vote in the EU referendum? Retrieved from theguardian.com: https://www.theguardian.com/politics/nginteractive/2016/feb/23/how-will-your-mp-vote-in-the-eu-referendum

Ruryk, J. (2016, Juni 24). Brexit voters may have been driven by fear more than reason. Retrieved from CBC News: http://www.cbc.ca/m/touch/world/story/1.3651073

Sari, A. P. (2016, 2 20). Cameron: Uni Eropa Beri Status Spesial kepada Inggris. Retrieved from CNN Indonesia: http://www.cnnindonesia.com/internasional/20160220151254-134112253/cameron-uni-eropa-beri-status-spesial-kepada-inggris/

Unesco. (2000). behaviour modification. Regional Training Seminar on Guidance and Counselling (p. 9). Uganda: Ag2i Communication.

Watt, P. W. (2016, mei 26). Ukip wins European elections with ease to set off political earthquake. Retrieved from The Guardian: https://www.theguardian.com/politics/2014/may/26/ukip-european-elections-politicalearthquake

Wells, A. (2015, September 22). Analysis: EU referendum - the state of public opinion. Retrieved from Yougov.co.uk: https://yougov.co.uk/news/2015/09/22/eu-referendumstate-public-opinion/

Worley, w. (2016, Juni 30). Donald Trump inspired Brexit campaign because facts don't work, says Leave founder Arron Banks. Retrieved from The Independent: http://www.independent.co.uk/news/uk/home-news/brexit-news-donald-trump-leave-eucampaign-facts-dont-work-arron-banks-lies-referendum-a7111001.html 


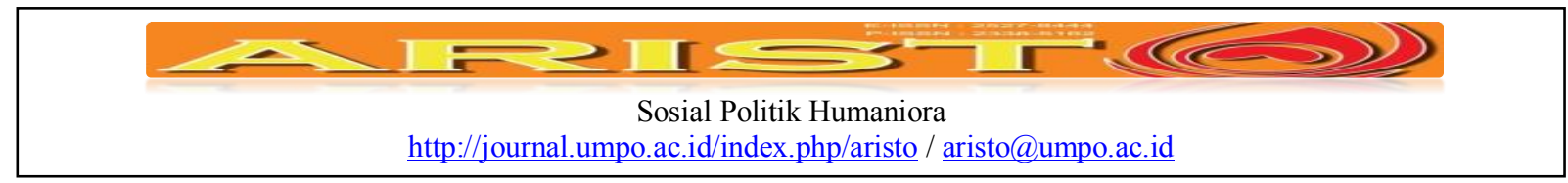

Zoega, G. (2016, September 1). On the causes of Brexit: Regional differences in economic prosperity and voting behaviour. Retrieved from Voxeu.org: http://voxeu.org/article/brexit-economic-prosperity-and-voting-behaviour 